\title{
Local Long-term Institutions, Growth, and Cash Holdings
}

\author{
By Kiyoung Chang ${ }^{*}$, Eun $\mathrm{Kang}^{\dagger}$, and Ying $\mathrm{Li}^{\ddagger}$
}

Keyword: local institution, cash, growth, monitor

JEL classification: G23, G32

${ }^{*}$ College of Business, University of South Florida Sarasota-Manatee, Sarasota, FL 34343

${ }^{\dagger}$ Corresponding author, College of Business Administration, California State University San Marcos, San Marcos, CA 92096, Tel: 1-760-750-4223, email: ekang@ csusm.edu

${ }^{\dagger}$ School of Business, University of Washington, Bothell, WA 98011 


\begin{abstract}
We provide empirical evidence that support both "outcome" and "substitute" models of agency theories related to cash holding. Local long-term institutional investors are associated with lower excess cash in firms with less growth and easier access to external financing, and with higher excess cash in firms with higher growth in our U.S. sample.
\end{abstract}




\section{Introduction}

U.S. firms continue to hold historically high stockpile of cash, which has long been documented to be a source of potential agency problems (Jensen, 1986, Opler et al., 1999, etc.). La Porta et al. (2000) propose two different types of agency models: "outcome" model and "substitute" model, which predict opposite relation between shareholder power and dividend payouts. Empirical studies have provided supporting evidence for both, but not within a same sample: the international evidence is consistent with the "outcome" model, while the U.S. evidence is consistent with the "substitute" model. This study attempts to reconcile the two models within the same U.S. sample by exploring the impact of monitoring institutions on excess corporate cash holding.

Institutions, if they care to monitor, are likely to exert their influence on cash holdings that are agency problem prone. From Kerkorian against Chrysler in 1996 to Einhorn against Apple in 2013, institutional investors have shown persistence in their pursuit of less excess cash holding to create value for firms. Under a cost-benefit analysis framework, it would be more costeffective for long-term institutional investors to play a monitoring role (Chen et al., 2007). Further, the local bias literature suggests that local long-term institutions' cost of monitoring may be lower due to their geographic proximity (Lerner, 1986, Chhaochharia et al., 2012).

"Outcome" model suggests that effective shareholder monitoring will reduce the amount of excess cash holding by entrenched managers. Anecdotal evidence shows that institutions attack cash holding at firms that tend to have reached the mature stage of their lifecycles and become a cash cow. These firms, with less growth opportunities, are likely to have more discretion over their cash holdings. We expect that "outcome" model should prevail for mature firms with no financial constraint as these firms have more cash to waste. 
"Substitute" model argues that the agency problem is alleviated with effective monitoring.. We use the term in the context of corporate cash holding and predict that monitoring institutions would support excess cash holding at growth firms to prevent underinvestment due to costly external financing as explained in Harford et al. (2008).

We choose local long-term institutional ownership (LLTIO) as our proxy for monitoring institutions and explore the relation between monitoring institutions and excess corporate cash holding in firms with high and low growth prospects. In general, firms with low growth prospects are mature firms with investment-graded long-term debt that have easy access to external financing, and firms with high growth prospects are young firms with no long-term debt and rating. Using a sample of 65,634 firm-year observations in the U.S., we show that higher LLTIO is associated with significantly lower (and negative) excess cash holding for firms with long-term investment grade debt and that higher LLTIO is associated with significantly higher (and positive) excess cash holding for firms with no long-term debt or rating. The former is consistent with predictions from the "outcome" model, as LLTIO exerts its monitoring power without worrying access to external financing. The latter is consistent with predictions from the "substitute" model since management shares interest with LLTIO either due to high growth or the need to access external financing. Our study thus provide fresh evidence that both "outcome" and "substitute" models could provide interpretation for corporate cash holding in the U.S., when we differentiate firm growth prospects, consider effective local monitors and control for easy access to external financing.

\section{Data}

\subsection{Institutional Ownership Measures}


We use Thompson Reuters' 13F quarterly institutional common stock holdings data for the institutional ownership measures. We follow the literature on local ownership and use location of corporate headquarters of the management company as the base to identify local institutional investors. The location and other firm-level financial variables are obtained from Compustat. We calculate the percentage of all institutional investors whose headquarters are located within a 100 miles radius around firm headquarters and use it as a proxy for local institutional ownership (Localown). Following Gaspar and Massa (2007), Localown is calculated as:

$$
\text { Localown }=\frac{\sum_{i \in L_{j}} V_{i, j}}{\sum_{i \in I} V_{i, j}}
$$

where $L_{j}$ is the set of local institutional investors (within 100 miles of the headquarters of stock $j$ ), I is the universe of institutional investors, $V_{i, j}$ is the dollar value of institution i's stake in stock $\mathrm{j}$.

We follow Bushee (1998) approach to classify long-term institutional ownership as transient, dedicated, and quasi-indexers based on the past investment patterns in the areas of portfolio turnover, diversification, and momentum trading. We focus on LLTIO$^{1}$ as Bushee $(1998,2001)$ points out that long-term institutional investors are more likely to monitor. Non-local long-term institutional investors (NLLTIO) are long-term institutional investors located more than 100 miles away from firm headquarters.

\subsection{Excess Corporate Cash Holding}

We source other financial variables from Compustat to calculate excess corporate cash holdings. We combine firm fixed effects with the standard empirical model that estimates cash required for operations and investments in the literature (Opler et al., 1999) and calculate excess cash holding as the residual from the model.

\footnotetext{
${ }^{1}$ LLTIO includes both local dedicated investors and quasi-indexers since both are geared toward long-term benefits as pointed out in Bushee (2001).
} 
Table 1 presents definitions and summary statistics of our major variables in our sample of U.S. firms. The mean LLTIO is $2.4 \%$ and the mean NLLTIO is $20.9 \%$. Consistent with the consensus that firms with high growth tend to use less or no leverage, we see from Table 1 that firms without long-term debt have much higher Tobin's Q, the proxy for a firm's growth potential ${ }^{2}$, and firms with long-term investment grade debt have lower Tobin's Q, supporting our classification of high and low growth firms based on the leverage. Excess cash holding (ExcessCash) has a mean of virtually 0, consistent with being a residual term, and a median of 0.286 .

\section{Results}

We present in Table 2 results from comparing the excess cash holding of firms with investment-graded long-term debt, and with no long-term debt and no rating, when local longterm institutional ownership is above-average and below-average. LLTIO is lagged by one year to alleviate endogeneity concerns. Firms with long-term debt have negative excess cash, with a mean of -0.26 , while the firms without long-term debt hold positive excess cash, with a mean value of 0.41. In Panel A, higher LLTIO is associated with significantly lower excess cash holding (-0.34) compared to lower LLTIO (-0.21). The result is consistent with the "outcome" model, which predicts lower cash holding in firms with less growth prospect, easy access to external financing and presence of powerful monitors.

In Panel B, higher LLTIO is associated with significantly higher amount of excess cash holding (0.57) compared to lower LLTIO (0.36). The result is consistent with predictions from the "substitute" model for firms with high growth and no easy access to external financing.

\footnotetext{
${ }^{2}$ Similar results are found for market-to-book ratio, which proxies for growth in Opler, et al (1999).
} 
NLLTIO does not seem to be as powerful monitors on corporate cash holding as LLTIO. As Table 2 shows, NLLTIO is similar to LLTIO in being positively associated with excess cash holding for firms with high growth, confirming the prediction from "substitute" model. However, higher level of NLLTIO is not associated with lower excess cash holding in firms that carry investment-graded long-term debt. So we do not find empirical support for "outcome" of NLLTIO's monitoring role, if there is any.

\section{Conclusion}

Our empirical findings provide fresh U.S. evidence for relation between monitors and cash holding that are consistent with predictions from both "outcome" model and "substitute" model. When we investigate a more likely monitor, LLTIO, due to geographic proximity, and consider the potential severity of agency problems at firms with and without growth opportunities, and introduce investment grade debt rating to differentiate the cost of external financing, we observe stark contrast of relation between LLTIO and excess cash holding: LLTIO pushes for lower excess cash holding at firms with potentially high agency costs and allows for higher excess cash holding at firms with less severe agency problems. 


\section{References}

Bushee, B. J., 1998. The influence of institutional investors on myopic R\&D investment Behavior. The Accounting Review 73, 305-333.

Bushee, B. J., 2001. Do institutional investors prefer near-term earnings over long-run value?. Contemporary Accounting Research 18, 207-246.

Chen, X., Harford, J., and Li, K., 2007. Monitoring: Which institutions matter?. Journal of Financial Economics 86, 279-305.

Chhaochharia, V., Kumar, A., and Niessen-Ruenzi, A., 2012. Local investors and corporate governance. Journal of Accounting and Economics 54, 42-67.

Gaspar, J. and Massa, M., 2007. Local ownership as private information: Evidence on the monitoring-liquidity trade-off. Journal of Financial Economics 83, 751-792.

Harford, J., Mansi, S. A., and Maxwell, W. F., 2008. Corporate governance and firm cash holdings in the US. Journal of Financial Economics 87, 535-555.

Jensen, M., 1986. Agency cost of free cash flow, corporate finance, and takeovers. American Economic Review Papers and Proceedings 76, 323-329.

La Porta, R., Lopez-de-silanes, F., Shleifer, A., and Vishny, R.W., 2000. Agency problems and dividend policies around the world. Journal of Finance 60, 1-33.

Lerner, J, 1995. Venture capitalists and the oversight of private firms. The Journal of Finance 50, 301-318.

Opler, T., Pinkowitz, L., Stulz, R., and Willamson, R., 1999. The determinant and implications of corporate cash holdings. Journal of Financial Economics 52, 3-46. 


\section{Table 1}

Descriptive Statistics of Major Variables

(All variables are winsorized at $1 \%$ and $99 \%$.)

\begin{tabular}{lccc}
\hline Variable & $\mathrm{N}$ & Mean & Median \\
\hline TA & 65364 & 1434 & 168 \\
Cash/TA & 65351 & 0.203 & 0.105 \\
Tobin's Q & 64970 & 2.172 & 1.548 \\
$\quad$ Investment-graded firms & 5085 & 2.040 & 1.684 \\
$\quad$ No long-term debt or rating firms & 10298 & 2.915 & 1.965 \\
$\quad$ Two-sample t/z test on difference & & $(17.634 * * *)$ & $(12.094 * * *)$ \\
LocalOwn & 65364 & 0.036 & 0.002 \\
LLTIO & 65364 & 0.024 & 0.000 \\
NLLTIO & 65364 & 0.209 & 0.165 \\
Rated & 65364 & 0.214 & 0 \\
Invgrade & 14001 & 0.456 & 0 \\
ExcessCash & 53951 & 0.000 & 0.286 \\
\hline
\end{tabular}

Notes: TA is a firm's total assets in millions of U.S. dollars. Cash/TA is a firm's cash and cash equivalents divided by total assets. Tobin's $Q$ is market value of total assets/book value of total assets. A two-sample $\mathrm{t} / \mathrm{z}$-test is conducted on difference in mean/median $\mathrm{Q}$ for firms with investment-graded long-term debt and those with no long-term debt or rating and $t / z$-statistics are reported in parentheses. LocalOwn is local institutional ownership. LLTIO and NLLTIO is local and non-local long-term institutional ownership, respectively. Rated takes one if the firm has S\&P bond rating, else 0. Invgrade takes one if the firm has S\&P bond rating BBB- and above, else 0 for only rated firms. ExcessCash is residual from regression on cash required for operations and investments following Opler et. al. (1999). 
Table 2

Firms' excess cash holding conditional on LLTIO and NLLTIO

Panel A. Excess cash hoding in firms with investment-graded long-term debt

\begin{tabular}{l|llll}
\hline Group & Obs & LLTIO & Obs & NLLTIO \\
\hline H & 2117 & -0.35 & 4721 & -0.25 \\
L & 2968 & -0.21 & 364 & -0.50 \\
Difference H-L & & $-0.14 * * *$ & & $0.25^{* * *}$ \\
T-stat on difference & & $(-4.15)$ & & $(4.00)$ \\
Overall group mean & 5085 & -0.26 & & \\
\hline
\end{tabular}

Panel B. Firms with no long-term debt and no rating

\begin{tabular}{l|llll}
\hline Group & Obs & LLTIO & Obs & NLLTIO \\
\hline $\mathrm{H}$ & 2367 & 0.570 & 3646 & 0.563 \\
$\mathrm{~L}$ & 7931 & 0.360 & 6652 & 0.323 \\
Difference H-L & & $0.210^{* * *}$ & & $0.239 * * *$ \\
T-stat on difference & & $(9.113)$ & & $(11.816)$ \\
Overall group mean & & & & \\
& 10298 & 0.41 & & \\
\hline
\end{tabular}

Notes: Group H represents firms with above-mean LLTIO or NLLTIO while group L represents firms with below-mean LLTIO or NLLTIO. A two-sample t-test is conducted on the difference of excess cash holding between group $\mathrm{H}$ and group $\mathrm{L}$ firms and $\mathrm{t}$-statistics are reported in parentheses. 